\title{
Representações de Atena em ânforas de figuras negras do século VI a.C.: um exercício de análise iconográfica ${ }^{1}$
}

\author{
Larissa de Souza Correia* \\ Camila Diogo de Souza**
}

CORREIA, L.C; SOUZA, C.D. Representações de Atena em ânforas de figuras negras do século VI a.C.: um exercício de análise iconográfica. R. Museu Arq. Etn., 25: 83 $103,2015$.

Resumo: $O$ presente texto apresenta os principais resultados e reflexões obtidos a partir de um exercício de descrição iconográfica e análise iconológica proposto para um pequeno conjunto de ânforas áticas de figuras negras datadas do século VI a.C. Este recorte documental tem como temática central as representações da deusa Atena em uma ou em ambas as faces do vaso, visando compreendê-las por meio da relação com os demais temas iconográficos e com as demais personagens integrantes das cenas presentes nas ânforas. Os objetivos e a metodologia da pesquisa incluem a catalogação, descrição iconográfica e análise iconológica da cultura material selecionada, a cerâmica, comparando-a com alguns recortes da documentação literária. Pretende-se, assim, refletir e discutir os possíveis papéis e atributos da deusa enquanto figura feminina e masculina. Os resultados alcançados a partir dessa análise indicam aspectos de complementaridade nos atributos da divindade que lhe caracterizam qualitativos próprios dos universos masculino e feminino da sociedade ateniense do Período Arcaico, permitindo-lhe transitar entre ambos os espaços.

Palavras-chave: Atena, ânfora, representação, análise iconográfica.

\section{A técnica de figuras negras: a produção do estilo}

produção cerâmica denominada "figu-
Lras negras" configura uma técnica de

\footnotetext{
* Autora da monografia. Especialista em arqueologia pela Universidade de Santo Amaro, membro do Laboratório de Estudos sobre a Cerâmica Antiga (LECA) da Universidade Federal de Pelotas (UFPel) e professora de ensino fundamental II - Historia na rede municipal de São Paulo. larissasouzacorreia@hotmail.com

** Orientadora da monografia. Pós-doutoranda do Museu de Arqueologia e Etnologia da Universidade de São Paulo (MAE-USP), bolsista FAPESP. Líder do Grupo de Pesquisas em Práticas Mortuárias do Mediterrâneo Antigo (TAPHOS-MAE
}

pintura em vasos cujos indícios apontam para o surgimento no século VII a.C. em Corinto. Tal técnica consistia em desenhar os elementos figurativos do vaso em pigmento escuro, negro, deixando o fundo do vaso com sua cor natural, no caso terracota. Dessa maneira, os vasos se

-USP) e coordenadora/pesquisadora associada do Laboratório de Estudos sobre a Cerâmica Antiga (LECA) da Universidade Federal de Pelotas (UFPel). caumilasouza@usp.br

1 Este artigo é resultado da monografia apresentada para a obtenção do título de especialista no Programa de Pós-Graduação em Arqueologia, História e Sociedade da Universidade de Santo Amaro (UNISA), intitulada "Representações de Atena em ânforas de Figuras negras do século VI a.C.: um exercício de análise iconográfica". 
configuravam visualmente com quatro cores: a coloração avermelhada natural da argila queimada, o preto brilhante presente na maior parte das imagens, o vermelho cereja e o branco para a adição de alguns detalhes na imagem, sendo o branco inclusive utilizado como um elemento distintivo do gênero para representar a pele das figuras femininas. Notamos que essa representação da mulher com a pele mais clara que o homem também está presente na iconografia egípcia, segundo Robins:

"De fato, ao se observar a arte egípcia, constata-se uma diferenciação da cor da pele dada aos dois sexos: os homens são mostrados com uma coloração de tom marrom-vermelho escuro, o que pode ser um indicativo de que os homens passavam mais tempo expostos ao sol; as mulheres são mostradas com uma coloração de tom marrom amarelado claro, possivelmente como sinal de que suas vidas ocorriam dentro de casa e longe do sol" (Robins, 1989: 108, apud Baltazar, 2011:37-38).

O contorno das imagens era feito primeiramente por meio de incisões na argila e depois elas eram preenchidas com uma argila diluída que podia ou não conter pigmentos para dar uma tonalidade diferenciada, permitindo assim que o contraste entre o fundo terracota e a figura em preto se tornasse mais intenso, tornando as imagens mais bem elaboradas e complexas como atesta Beazley:

"Black-figure is the name of a technique. By black-figure one means not simple silhouette, but silhouette elaborated and enlivened in two ways: first, by plenty of details engraved with a sharp point, incised, as it is called; secondly, by plentiful addition of dark red paint, and of white paint, one of the chief uses of white being for female flesh. This gives a sober scheme of four colours: the orange of the ground, which is the native colour of the clay vase; the lustrous black of the glaze paint; the white; the deep cherry or crimson, sometimes purplish, red. The black-figure technique may seem very unrealistic, and so it is; but so is outline drawing, only we are more accustomed to it. If the Greek vase-painter had painted in outline on his orange surface, the effect would have been meagre, and the strong colour of the background would have eaten up the thin line. The black-figure technique gave contrast and a proper balance of light and dark" (Beazley, 1951: 1)².

\section{Na produção cerâmica de figuras negras,} a cena era pintada no vaso com uma pasta de argila líquida (convencional e tradicionalmente designada como verniz), que se tornava negra após a queima. Esta não era uma "cor" ou uma "tinta" no sentido tradicional, pois era constituída do mesmo material que o próprio vaso, apenas diferindo na quantidade das partículas minerais componentes. A cena como um todo e o contorno das grandes figuras eram feitos em esboço com carvão ou com instrumentos de incisão. As incisões também eram utilizadas para os detalhes internos das figuras, como os drapeados das roupas e os detalhes do rosto e do corpo.

Alguns detalhes das figuras, como adornos e partes das roupas, animais, como as crinas de cavalos, instrumentos ou armamentos, objetos em mármore, sangue, e ainda, partes do corpo, como cabelo e a pele da grande maioria das figuras femininas recebiam um tipo de pasta líquida diferenciada, com pigmentos que, após o processo de queima, adquiriam tons específicos em branco e vermelho. Para obter a cor branca, era utilizada uma argila pura, com uma quantidade mínima de óxido de ferro. Já a cor

2 "Figuras negras é um tipo de técnica caracterizada pela elaboração de silhuetas não simples, mas elaboradas e animadas de duas maneiras: em primeiro lugar, por uma abundância de detalhes gravados com uma ponta afiada, incisão, como é chamado; em segundo lugar, pela abundância de cor vermelha escura, e branca, sendo um dos principais usos da coloração branca a representação da pele feminina. A imagem é composta por um esquema sóbrio de quatro cores: a laranja da terra, a qual é a cor natural do vaso de argila; o preto brilhante do esmalte; o branco; a cereja profundo ou vermelho arroxeado e o vermelho. A técnica de Figuras negras pode parecer muito irreal, e assim o é; mas assim é delinear desenhar, apenas estamos mais acostumados a ele. Se o pintor de vaso grego pinta-se o esboço em sua superfície laranja, sem a incisão, o efeito teria sido escasso, e a cor forte do fundo teria comido até a linha fina. A técnica em figura-negra deu contraste e um bom equilíbrio de luz e escuridão". (tradução livre dos autores) 
vermelha era obtida através de uma argila líquida contendo grandes quantidades de óxido de ferro, de tonalidade amarela, laranja ou avermelhada que, após a queima, tornava-se vermelho ocre ou até mesmo púrpura.

Os estudos sobre as figuras negras começaram a se desenvolver principalmente a partir do século XVIII como afirma Dias:

"Muito do que se conhece acerca dos vasos gregos é fruto dos estudos iniciados no século XVIII. A observação e o conhecimento deste material ao longo dos séculos foi delineando o que viria a ser o estudo atual da cerâmica grega, embora inicialmente houvesse problemas cronológicos e classificatórios: ainda não haviam sido desenvolvidos métodos rigorosos para o estabelecimento de datações dos vasos que então, foram baseadas sobretudo nas fontes históricas. E, em um período ainda dominado pela "Etruscomania", os objetos que não fossem obviamente egípcios, romanos ou gregos foram classificados como etruscos" (Dias, 2009: 2).

Esse estudo da documentação material baseado na fonte escrita foi uma tendência bastante comum nesse período, quando a arqueologia encontra suas origens e fundamentos enquanto ciência ligada ao colecionismo e à História da Arte. Ainda hoje os estudos de História Antiga sofrem com a marginalização ou uso inadequado da cultura material enquanto ilustração do texto, como atesta Menezes:

"Na bibliografia recente de História da Grécia e de Roma, por exemplo (domínio que tomarei como referência principal), três posturas são marcantes.

A primeira é a simples marginalização da cultura material[...]

A segunda postura talvez seja a mais freqüente de todas. É caracterizada pelo uso de aspectos da vida material, mais precisamente, da informação arqueológica, de maneira puramente instrumental. O papel assim desempenhado pela documentação física seria o de controle e, nos casos mais felizes, complementação da documentação textual[...]
A terceira postura se pauta pelo uso "didático" das informações sobre o universo material. Estas se transformam consequentemente em ilustração daquilo que o texto já estabeleceu [...] Criam um clima que permitiria "vivenciar" situações, experiências e outras realidades que os textos nos restituem de maneira apenas verbal[...]" (Menezes, 1983: 103-105).

Entre os séculos XIX e XX o estudo dos vasos áticos se desenvolve por meio do método de atribuição, segundo o qual, a partir de alguns vasos que possuíam a assinatura do pintor, foi possível definir traços estilísticos específicos de cada pintor, grupo ou oficina e, assim, em conjunto com o estudo das características de argila, contextualizar o próprio local de produção do vaso.

É importante ressaltar que, muitas vezes, o local no qual tais vasos foram escavados não corresponde necessariamente ao seu local de produção, já que muitos vasos eram exportados para regiões diversas e longínquas. $\mathrm{O}$ conhecimento dos estilos iconográficos de cada oficina em cada região permitiu, de um lado, uma compreensão mais precisa do ambiente de origem do vaso, e de outro, permitiu delinear os termos proveniência enquanto o local de achado, o contexto arqueológico onde o vaso foi encontrado, e o termo centro de produção enquanto o local onde o vaso foi confeccionado.

\section{O suporte material: as ânforas.}

O suporte material das imagens analisadas é formado pelas ânforas, uma forma específica de vasos gregos, classificada como um recipiente fechado com grande durabilidade e encontrada abundantemente em todo Mediterrâneo. A ânfora é um vaso utilizado para estocagem e transporte de líquidos e sólidos, como vinho, azeite, água e grãos. Trata-se de uma forma de vaso encontrada desde o Neolítico na Europa e na Ásia Menor. Na Grécia, aparece em grande quantidade durante todo o Período Heládico ${ }^{3}$. As classificações morfológicas das ânforas são bastante variadas. Segundo as classificações de Gisela Richter (1996) e John Beazley (1951), há 
três grandes grupos: as ânforas panatenaicas, as do tipo belly e as ânforas do tipo neck ${ }^{4}$.

O termo ânfora, já consagrado na Língua Portuguesa, origina-se de amphoréus (do grego antigo: $\alpha \mu \varphi \circ \rho \varepsilon v ́ \varsigma)$, abreviação de amphiphoréus

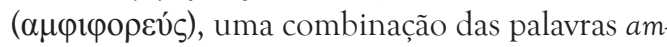
phi- que significa "ambos os lados" com o termo -phoreus que significa "carregador", "suporte" e é derivado do verbo carregar, portar em grego. Refere-se, portanto, aos vasos que possuem duas alças fixadas de maneira simetricamente oposta. $O$ corpo da ânfora apresenta sempre o maior diâmetro do vaso na parte superior da pança, caracterizando, portanto, um corpo superior mais arredondando e amplo e que apresenta um estrangulamento acentuado na parte inferior do vaso, semelhante a um cone invertido. $O$ pescoço, em geral, é estreito, retilíneo ou ligeira e proporcionalmente curto em relação ao resto do vaso. A base da ânfora termina sempre em um tipo de pé, geralmente alto e em anel, aberto para o exterior. Em alguns casos, o pé constitui um pedestal. As alças correspondem também a um elemento morfológico bastante variável da ânfora, podem ser verticais ou horizontais. As alças verticais possuem a extremidade superior fixadas na borda ou no pescoço, enquanto a extremidade inferior é fixada na pança, em geral, no ombro do vaso, na área em que se encontra o maior diâmetro do vaso. Elas podem

3 O Período Heládico corresponde aproximadamente ao intervalo entre 2800 a.C. a 1100 a.C. e é equivalente a chamada Idade do Bronze na Grécia Continental. Trata-se de um longo período da História da Grécia que é geralmente dividido em três fases: Heládico Antigo (2800 a.C. a 2100 a.C.), Heládico Médio (2100 a.C. a 1550 a.C.) e Heládico Recente (1550 a.C. a 1100 a.C.). Este último período corresponde ao Período Micênico. Tanto o Heládico Antigo quanto o Heládico Recente ou Período Micênico podem ainda ser subdivididos em três subfases, tradicionalmente denominadas I, II e III. As formas de vasos cerâmicos já se apresentam bastante variadas neste período da Proto-história Grega e variações morfológicas da ânfora são verificadas desde o Heládico Antigo como vasos mais rústicos utilizados para estocagem de alimentos. VERMEULE, E. Greece in the Bronze Age. Chicago, London: University of Chicago Press, 1964

4 As características morfológicas que definem cada um dos tipos de ânforas são apresentadas nas páginas do site do arquivo Beazley: http://www.beazley.ox.ac.uk/tools/pottery/ shapes/amphorae.htm ser de dois tipos: cilíndricas ou planas. As alças horizontais situam-se sempre na altura da pança onde se encontra o diâmetro máximo da ânfora, isto é, no ombro. Na maioria dos vasos, elas são cilíndricas e podem formar um único arco ou podem formar arcos duplos, como um M.

\section{Atena Prómakhos e Atena Palladium}

Em primeiro lugar, faz-se necessário definir alguns elementos iconográficos que caracterizam o objeto central de análise; isto é, a representação de Atena, a fim de proporcionar os recursos e os fundamentos da proposta de leitura iconológica. As representações da deusa nos vasos catalogados apresentam um conjunto de elementos que permite classificá-las em dois tipos: a Atena Palladium e a Atena Prómakhos (Francisco, 2012: 50-51, 64). Tratam-se de representações iconográficas da deusa Atena recorrentes, sobretudo, no repertório das primeiras ânforas de figuras negras, inclusive nas ânforas panatenaicas. As definições dos epítetos estão na diferença da representação iconográfica dos gestos da deusa:

"A Atena panatenaica, chamada Prómakhos, parece compor um esquema figurativo presente na produção artesanal do Mundo Grego desde o século VII a.C. em suportes diversos, e essa forma de apresentar a deusa já era comum nas oficinas coríntias, remontando a produção protocoríntia (séc. VII a.C.) $[\ldots]$

[...] A coerência modernamente criada, ligada à definição da Atena Prómakhos presente no LIMC, não opera de forma positiva na identificação de um esquema figurativo específico, que é baseada, sobretudo no tema (a deusa Atena combativa) e nos atributos (a lança e o escudo associados). Aqui, assumese que o gesto é um elemento importante: a figura de Atena em passo à frente, segurando numa mão uma lança em posição de ataque, e um escudo em posição de proteção (ambos altos) e portanto algum outros elementos como o gorgoneion, o capacete e o quiton longo" (Francisco, 2012: 50). 
A representação de Atena Prómakhos, portanto, segue um padrão rígido, no qual a deusa é desenhada de perfil, empunhando uma lança em uma mão e o escudo na outra. Seus pés aparecem separados e o calcanhar do pé que está atrás, à direita da composição, apresenta-se ligeiramente elevado para dar a ideia de movimento, ação. A deusa porta sempre um elmo, elemento, portanto, qualificativo de sua função. Dessa forma, Prómakhos é uma caracterização da deusa nitidamente ligada aos elementos que compõem o universo masculino: o ataque, a guerra, e que ressaltam seus atributos de força e coragem, típicos da deusa guerreira.

A representação iconográfica da Atena Palladium, assemelha-se, em grande medida, àquela utilizada para a deusa enquanto seus atributos de Atena Prómakhos. Ela aparece na mesma posição lateral, de perfil, portando o escudo, em muitos casos, a lança, porém, raramente, o elmo. Contudo, a diferença essencial está no desenho dos pés. Na grande maioria das vezes, eles aparecem juntos, ou quando separados, encontram-se afastados por uma pequena distância, com uma abertura reduzida das pernas e ambos inteiramente no chão. Tal representação indica uma posição estática, imóvel da personagem e, portanto, representa uma estátua da divindade. Os elementos semelhantes da representação iconográfica da Atena Palladium com a Atena Prómakhos são bem elencados por Francisco:

"Para além da questão da derivação, é importante observar que a distinção entra a Atena Prómakhos (como aqui proposto) e a figura do Palladium resido no gesto: se a Atena Prómakhos é caracterizada em

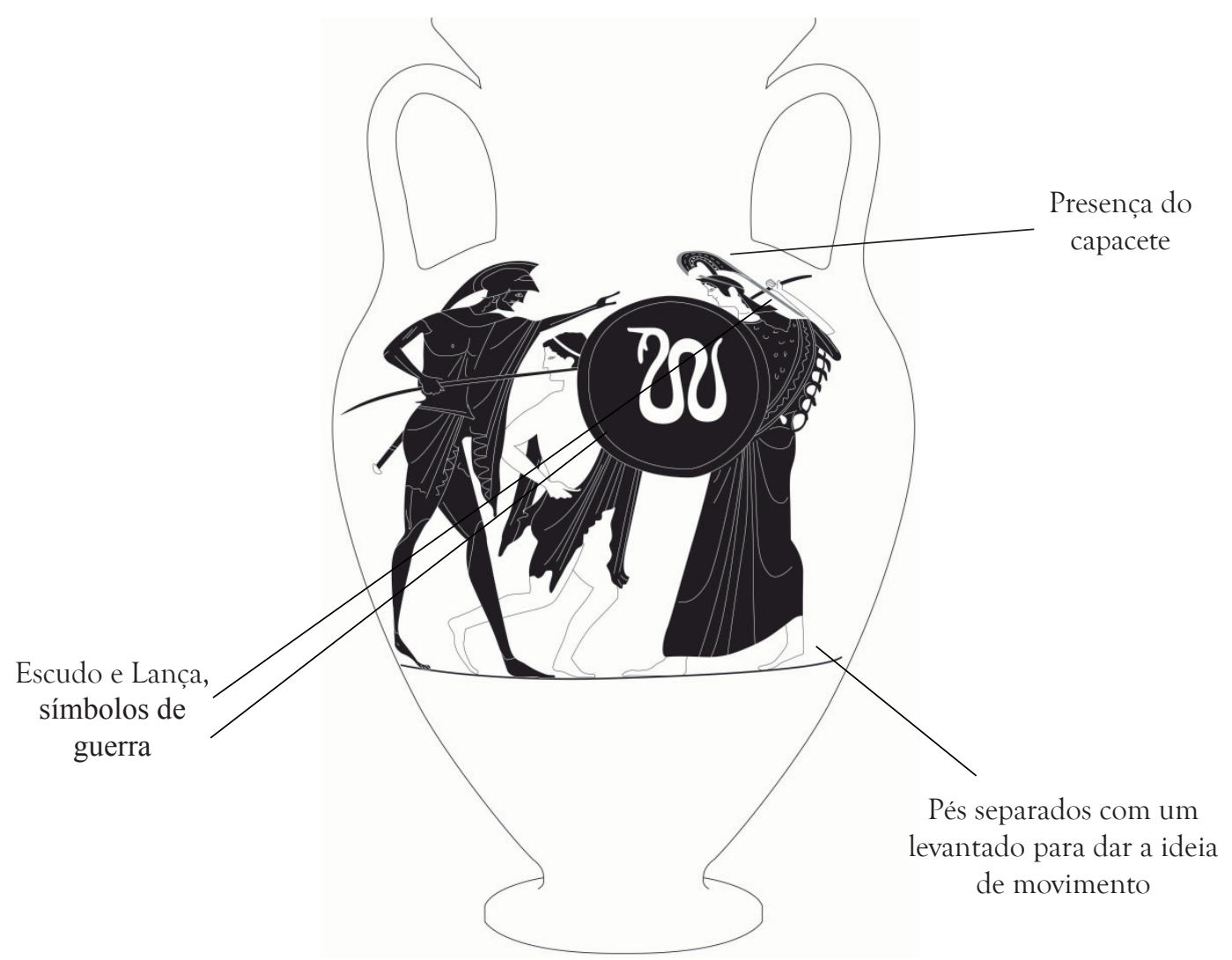

Fig. 1. Elementos iconográficos da representação da Atena Prómakhos. Desenho: Yannis Nakas (2015). 
movimento (o passa aberto indicando certa projeção para frente), o Palladium tem os pés juntos, o que o situaria como figura de estátua, ma há um grupo coeso de figuras do Palladium que tem a lança e o escudo em situação bastante similar à da Atena Prómakhos. Tal aproximação não é artificial, se se notar que em contextos específicos alguns artesão usaram a Atena com pés juntos na produção de ânforas panatenaicas [...], aproximando, com isso, figuras atualmente caracterizadas como Atena Prómakhos e Palladium" (Francisco, 2012: 51).

\section{A figura de Atena Palladium é comumente} representada junto à Cassandra, indicando uma cena do mito que envolve as personagens. Abordaremos tal questão no item reservado à análise iconológica, apresentado nas próximas páginas.

Já a representação de Atena Prómakhos traz em si elementos característicos da guerra, como a lança, o escudo e o elmo. Esses elementos acompanhados da atitude de ataque ressaltam os atributos de deusa guerreira que caracterizam a Aretê masculina (do grego an-

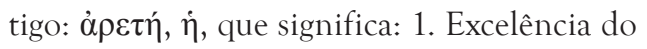
corpo, força, agilidade, saúde 3. Excelência da alma, virtude, coragem, denodo 4. Excelência, mérito 5. Eficácia, virtude, castidade, virgindade, pureza 6. Honra, consideração 7. PL. Atos virtuosos, proezas) $)^{5}$.

5 MALHADAS, D.; DEZOTTI, M. C. C.; NEVES, M. H. M. (org.) DICIONARIO GREGO-PORTUGUES, V.4 ( $\boldsymbol{\alpha}-\boldsymbol{\delta})$. Cotia: Ateliê Editorial, 2006,p. 128
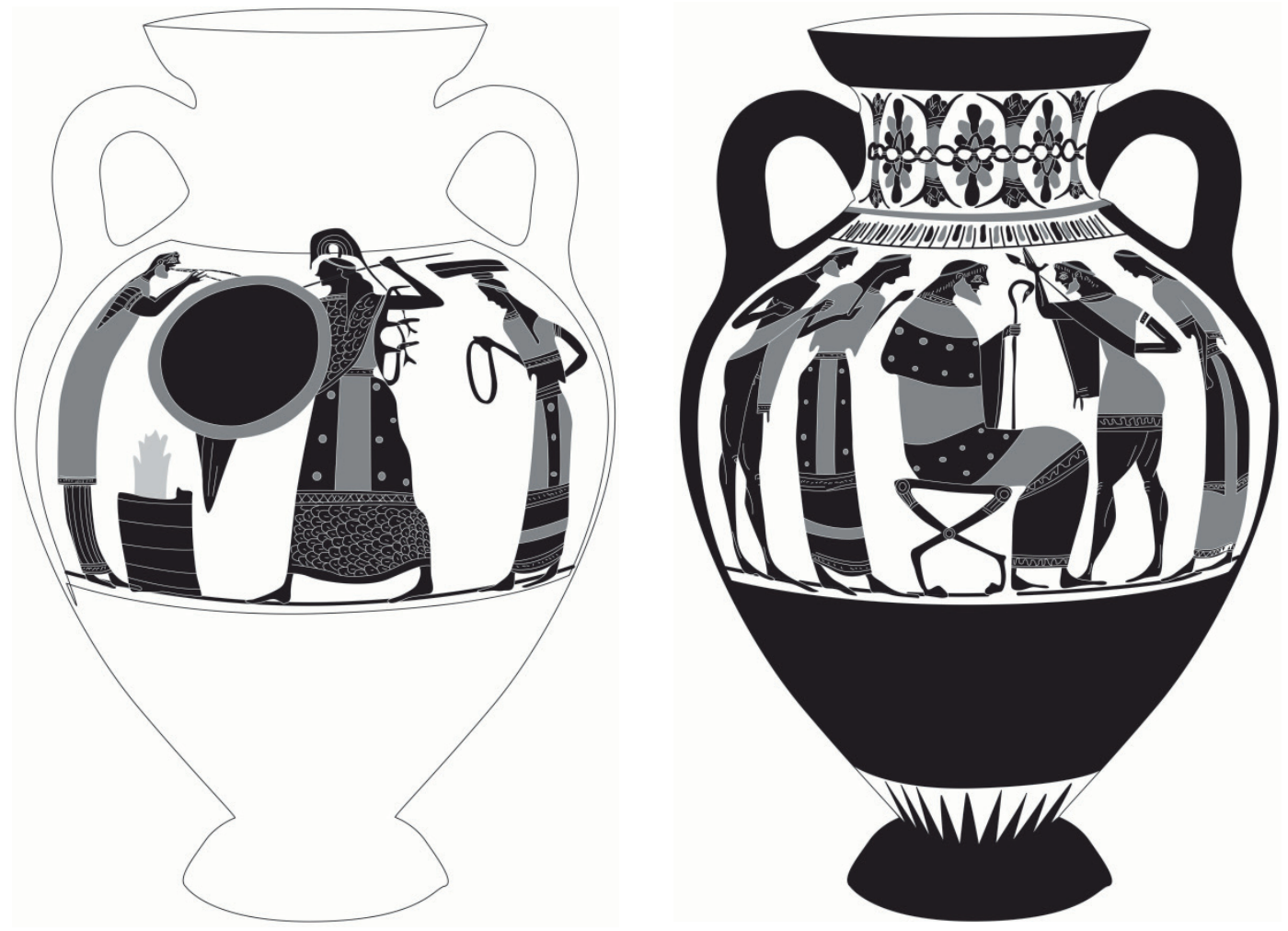

Fig 2. Face A e Face B do vaso no 01: Metropolitan Museum: 53.11.1; Número arquivo Beazley: 320404. Desenho: Yannis Nakas (2015). 


\section{Ânforas panatenaicas e a iconografia das Pana- teneias.}

É importante ressaltar que a Atena Prómakhos é uma representação típica das ânforas panatenaicas e que essas ânforas eram um objeto importante nas panateneias ou festivais panatenaicos. As Panateneias (do grego:

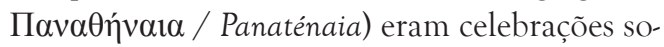
ciais e religiosas da cidade de Atenas. $\mathrm{O}$ festival Panatenaico era anual e era realizado de 23 a

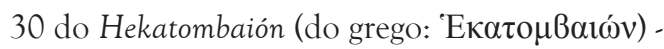
primeiro mês do ano ático, equivalente à segunda metade de nosso corrente mês de Julho. A cada quatro anos ocorriam as Grandes Panateneias, que incluíam jogos, rituais, musicais, danças e banquetes e duravam mais dias que as Pequenas Panateneias, realizadas anualmente.

Ao analisarmos as cenas da ânfora número 01 (Metropolitan Museum: 53.11.1; Número arquivo Beazley: 320404$)^{6}$, notamos que a cena da face A (fig. 2), onde se encontra a representação da Atena Prómakhos, e a cena presente na face B do vaso apresentam representações de personagens típicos dos participantes das festividades em homenagem à deusa.

6 Referências bibliográficas sobre o vaso: Antike Kunst: 33 (1990) PL.18.4; Beazley, J. D., Attic Black-Figure Vase-Painters (Oxford, 1956): 298.5; Carpenter, T.H., with Mannack, T., and Mendonca, M., Beazley Addenda, 2nd edition (Oxford, 1989): 78. Corpus Vasorum Antiquorum: NEW YORK, METROPOLITAN MUSEUM OF ART 4, 12-13, PL. (741) 13.1-4; Greek Vases in the J. Paul Getty Museum 6 (2000): 61, FIG.3 (A); Kaltsas, N. and Shapiro, A., Worshiping Women, Ritual and Reality in Classical Athens (Athens and New York, 2008): 30, 258, NO.117 (COLOUR OF A, B AND PART OF A); Metropolitan Museum Journal: 42 (2007) 29, FIGS.14-15, COLOUR PLATE 1 (A, B, COLOUR OF A); Neils, J., et al., Goddess and Polis, The Panathenaic Festival in Ancient Athens (Princeton, 1992): 25, FIG.14 (A); Reeder, E.D., et al., Pandora, Women in Classical Greece (Baltimore, 1995): 42, FIG.7 (A) Shapiro, H.A., Art and Cult under the Tyrants in Athens (Mainz, 1989): PL.14B (A). Este vaso apresenta um problema de restauração efetuada pelo Metropolitan Museum of Art, pois originalmente, o vaso apresentava o trípode em pintura branca como epísema do escudo da Athena Prómakhos e as pelas da própria deusa e das figuras femininas eram escuras, preenchidas pelo verniz negro, porém estavam em um péssimo estado de conservação, encontrando-se bastante descascadas. O epísema e o estado mal preservado das figuras foram registrados por Beazley no momento em que o pesquisador estudou os vasos e as fotos com tais informações se encontram
$\mathrm{Na}$ face A, o jovem tocando a flauta indica a presença da música nas panateneias. A jovem presente à direita da deusa representa provavelmente uma das canéphorae, (do grego:

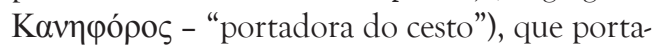
vam os instrumentos sacrificiais dentro de um cesto para ser levado até o templo da deusa onde seriam realizados os sacrifícios em sua homenagem. A jovem é representada com um cesto na cabeça e uma fita na mão, ela porta um vestido longo e os cabelos longos estão presos com uma tiara. Todos esses elementos iconográficos são característicos da representação dos membros femininos da aristocracia ateniense que denotam as jovens virgens participantes dos festivais.

Além disso, na face B notamos a presença de jovens do sexo masculino e feminino que cercam uma figura de um ancião portando um cetro; representação iconográfica que sugere a identificação provável de um membro destacado social e politicamente da aristocracia ateniense com papel e participação fundamental nos festivais panatenaicos.

O caráter ritual do vaso indicado pelos participantes das festividades pode ser ainda complementado imageticamente pela presença

no próprio arquivo Beazley, em preto e branco. Contudo, o vaso foi restaurado posteriormente pelo Metropolitan $\mathrm{Mu}$ seum af Art, as figuras femininas receberam pintura negra para indicar que originalmente sua pele era preenchida pelo verniz, porém o vaso trípode em pintura branca que estava representado no escudo da Atena não foi restaurado e, dessa maneira, o escudo da deusa encontra-se atualmente todo em verniz negro, como se não houvesse nenhum elemento iconográfico representado enquanto epísema. Esta imagem do vaso restaurado, porém sem o trípode no escudo da deusa, foi publicada no CVA do referido museu em 1976, Prancha 741 e encontra-se no site do museu em imagem colorida. A disponibilização e autorização para publicação e desenho deste vaso foi obtida por meio do Metropolitan Museum a partir da imagem publicada no CVA e disponível no site do Museu, fato que ocasionou a ausência do trípode enquanto episema no desenho por parte do desenhista Yannis Nakas. Após a verificação do ocorrido, o desenho foi refeito a partir das fotos em repto e branco do arquivo Beazley, fato que explica, portanto, a pele das figuras femininas representadas em branco. Indicamos, assim, a problemática da restauração, da realização dos desenhos a partir das fotos distintas e a presença de desenhos e representações distintas desses dois elementos iconográficos das ânforas selecionadas para estudo, o epísema em trípode e a coloração da pele da deusa e da figura feminina que se encontra à sua direita. 
do vaso do tipo trípode enquanto epísema no escudo da deusa. Esse tipo de vaso é usado especificamente em contexto ritualístico como nos atesta Morgan (1990). Os vasos do tipo trípode (forma latinizada do grego antigo: $\tau \rho i ́ \pi o v \varsigma$, no genitivo, $\tau \rho i ́ \pi o \delta o \varsigma$, que significa literalmente "três pés", tripé) trata-se de uma forma utilizada em contextos sagrados, como oferendas, como vasos sacrificiais ou como mobiliário religioso (assentos) utilizado durante os rituais. Os aspectos morfológicos do vaso explicitam e reforçam a estabilidade do vaso e fazem com que seja uma forma muito antiga, que aparece desde o Neolítico na Ásia e na Europa. Na Grécia Antiga, eles são mencionados nas obras homéricas como prêmios e presentes ofertados aos heróis e líderes políticos, ou também como prêmios para os vencedores dos jogos fúnebres (Ilíada, XXIII: v. 884; XXIV: v. 233; Odisseia, XIII: v. 13). Durante os Períodos Arcaico e Clássico, ele é particularmente associado com Apolo e com o oráculo de Delfos, por meio da pítia ou da também denominada pitonisa (em grego: ПvӨía, transl. Pythía, que significa "serpente"), a sacerdotisa do templo, responsável pelas profecias inspiradas por Apolo. As trípodes mais antigas do santuário de Apolo em Delfos aparecem no século VIII a.C. (Morgan, 1990). Verificamos, assim, que as cenas dos painéis iconográficos da face A e da face B da ânfora panatenaica são complementares e integram parte do universo das atividades rituais que envolvem as panatenaicas, representando os indivíduos que participavam das festividades.

\section{Atena e os heróis}

Um dos atributos de Atena que nos chama a atenção nas fontes literárias é o de deusa da guerra, frequentemente ligando sua representação junto ao herói, oferecendo-lhe auxílio na batalha. Durante a pesquisa realizada para a elaboração da monografia do curso de especialização em Arqueologia, verificamos que, em alguns dos vasos catalogados ${ }^{7}$ o papel da Atena enquanto tutora dos heróis pode ser verificado, sobretudo, quando comparamos as representações iconográficas com algumas passagens literárias.
Na Ilíada, obra cuja ação se passa em grande parte no campo de batalha, podemos perceber inúmeros episódios que destacam o caráter guerreiro da deusa, como por exemplo, na passagem abaixo em que a deusa auxilia o herói no campo de batalha:

Palas Atena, a donzela de Zeus, em Diomedes infunde força e coragem sem par; para que entre os Argivos pudesse sobressair mais que todos e glória imortal conquistasse

Inextinguível luzeiro faz do elmo surgir e do escudo, de brilho igual ao da estrela que, mais do que as outra, no outono incontrastável esplende, depois de banharse no oceano: com tal fulgor ao redor da cabeça e das largas espáduas, faz ela o herói avançar para o ponto mais densa da pugna. (Homero, Iliada, V-1-8: 127)

Nesta passagem, Atena (Palas) ampara Diomedes, na medida em que faz com que sua força e coragem aparentem ser maiores no campo de batalha, para que possa vencer seus oponentes. No mesmo poema há uma passagem na qual Odisseu é ferido e a deusa lhe preserva a vida:

A essas palavras, a lança the atira no escudo redondo; a arma terrível o escudo de aspecto brilhante atravessa, indo encravar-se na cota de bela e variada textura, toda a epiderme do flanco esflorando. Mas Palas Atena não permitiu que as entranhas do herói alcançar fosse o bronze. (Homero, Ilíada, XI 34-38: 465)

Se na Ilíada o ambiente do campo de batalha favorecia uma representação de Atena auxiliando o herói através da força e de seus atributos de deusa da guerra, na Odisseia, com seus cenários variados, notamos representações

7 CORREIA, Larissa. Representações de Atena em ânforas de figuras negras do século VI a.C.: um exercício de análise iconográfica. Monografia apresentada para a obtenção do título de especialista em Arqueologia do curso de Pós-graduação em Arqueologia, História e Sociedade da Universidade de Santo Amaro (UNISA) em 2014, p. 49, 59, 80, 83, 88, 90 
mais amplas dos atributos da deusa, trazendo entre várias características, a de deusa conselheira e encorajadora, inspiradora. Em diversos momentos, a deusa, com seus conselhos, auxilia Odisseu em sua trajetória de retorno ao lar:

Busca o porqueiro responsável pela vara, ante de mais ninguém. Nada mudou $\mathrm{o}$ afeto que ele nutre por ti, teu filhos e por Penélope.

Encontra-o com os suínos cujo patos abeira a rocha Corvo, acima de Aretusa, a fonte, onde devoram glandes de carvalho e bebem água escura: os engorda a floração untosa. (Homero, Odisséia, XIII 404-410: 407)

Embora o enredo da Odisséia se centre principalmente em Odisseu e seu retorno à Ítaca, a representação dos atributos de Atena enquanto tutora se faz mais presente em sua relação com Telêmaco, filho de Odisseu, em uma trajetória que Jaeger (1995) defini como Telemaquia, por se tratar da jornada de Telêmaco em busca do pai e, de certa forma, em busca de si próprio.

Sobre essa aparição de Atena disfarçada para Telêmaco, Jaeger (1995), apresenta a seguinte interpretação:

"Telêmaco presta atenção às advertências da deusa, disfarçada sob a figura do amigo e hóspede de seu pai, Mentes. É que as palavras de Mentes dizem-lhe a mesma coisa que lhe aconselham as vozes do seu próprio coração. Telêmaco é o protótipo do jovem dócil, a quem o conselho de um amigo experiente, aceito com gosto, conduz à ação e a gloria". (Jaeger, 1995: 53).

Para Jaeger, a mudança da aparência de Atena, constitui uma forma de se aproximar de Telêmaco de um modo mais familiar, sob um aspecto mais velho, para inspirar-lhe confiança e experiência; aspectos necessários nessa jornada que configura uma busca pela própria maturidade de Telêmaco. Dessa forma, à Atena é atribuído um papel de protetora, conselheira e educadora de Telêmaco, em seu percurso para se tornar um homem adulto.

É importante ressaltar, que como colocado por Florenzano (1996) os rapazes em Atenas passavam por uma série de rituais de iniciação para chegarem a vida adulta, esses rituais estavam diretamente ligados a formação do jovem, já que tinham como objetivo estabelecer padrões de comportamento e fixar valores esperados na vida adulta. Simultaneamente, tais rituais "reforçavam a distinção das funções desempenhadas na sociedade pelos dois sexos" (Florenzano, 1996: 21), à medida que os rituais femininos e masculinos possuíam aspectos distintos relativos papéis e funções dos homens e das mulheres na sociedade.

Nota-se que em Homero, Atena é uma figura crucial para o amadurecimento social de Telêmaco. Conforme afirma Jaeger, era necessário que Telêmaco amadurecesse para poder ajudar Odisseu a enfrentar os pretendentes quando retornasse à Ítaca. Tal afirmação evidencia o principal papel de Atena na Odisséia: proteger o herói Odisseu (JAEGER, 1995).

Essa necessidade de amadurecimento de Telêmaco é fundamental, pois como aponta Jaeger, o personagem era uma figura insegura e que não poderia auxiliar o pai na vingança contra os pretendentes. Sendo assim, foi necessário a intervenção de Atena para lhe converter no ideal de homem grego homérico tornando-se, dessa forma, num aliado do pai e ser capaz de ajudá-lo. Relembramos que a trajetória de amadurecimento de Telêmaco se inicia no momento em que Odisseu sai da ilha de Calipso e parte rumo à casa:

"O conjunto da Odisséia constitui uma linda criação composta de duas partes separadas: Ulisses, ausente e retido na ilha da ninfa apaixonada, rodeado de mar, e o seu filho inativo, à espera dele no lar abandonado. Ambos se põem em movimento ao mesmo tempo, para no fim se reunirem e presenciarem o regresso do herói" (Jaeger, 1995: 55).

É interessante analisar essa última frase de Jaeger "Ambos se põem em movimento 
ao mesmo tempo, para no fim se reunirem e presenciarem o regresso do herói”. Poderíamos nos questionar quem seria o herói mencionado na última frase de Jaeger. À princípio, muito provavelmente Odisseu, que traz em si desde a Ilíada todos os atributos heroicos: honra, coragem, astucia. Entretanto, Telêmaco passa da inatividade para o movimento ao mesmo tempo que Odisseu inicia seu regresso para Ítaca, através do amadurecido propiciado por Atena. Não seria esta sua transformação no próprio ideal de herói grego?

Se pensarmos em seu trajeto, seu caminhar até essa maturidade heroica, é possivel traçar um paralelo com os ritos de passagem para a idade adulta e inferir que de certa forma ao mesmo tempo em que a Odisseia traz o regresso de um herói para a casa, aponta também para a formação de outro.

Jaeger também aponta para a importância do feminino, do papel da mulher na formação do aristocrata grego. $\mathrm{O}$ autor reforça a formosura como elemento próprio da Aretê (do grego antigo: $\dot{\alpha} \rho \varepsilon \tau \eta ́)$ feminina, relembrando que "o culto da beleza feminina corresponde ao tipo de formação cortesão de todas as idades cavalheirescas" (Jaeger, 1995: 46), para assim explicitar a importância da formosura feminina naquele contexto.

Entretanto, Jaeger também coloca que o olhar do homem grego para a mulher não se limita simplesmente ao campo de sua beleza física, mas se estende à importância de seu papel social, tendo em vista sua responsabilidade de repassar a educação heroica ao homem e assim formar os futuros cidadãos, pois "[...] numa raça orgulhosa de cavaleiros, a mulher pode ser mãe de uma geração ilustre. Ela é a mantenedora e a guardiã dos mais altos costumes e tradições" (Jaeger, 1995: 47).

Essa importância do feminino na formação aristocrática explicitada pelo autor é a partir do espaço do oîkos, onde a mulher é quem gerencia e administra o ambiente e cria os jovens gregos lhes imputando a cultura e as normas de conduta considerados ideais naquele tipo de sociedade. Dessa forma, a cultura e tradição grega é repassada às futuras gerações através da figura feminina, da figura materna.
Assim, a condição da mulher dentro dessa cultura aristocrática seria não só a de geradora, como também de guardiã e preservadora, da mesma. Por outro lado, Loraux (1990: 52-53) nos mostra que, apesar da virgindade e de recusar o matrimônio, Atena também é guardiã não apenas de poucos filhos, mas de todo um grupo, simbolizada pelo "solo ático", retornando assim seus atributos ao mito original de deusa mãe.

Retomando a condição feminina de educadora, Jaeger aponta nessa síntese do papel pedagógico feminino, a relevância da presença de Atena enquanto guia de Telêmaco:

"Esta íntima e profunda civilização é o produto do influxo educador da mulher numa sociedade rudemente masculina violenta e guerreira. É na mais alta, íntima e pessoal relação do herói com a sua deusa Palas Atena, a qual o guia nas suas andanças e jamais o abandona, que o poder espiritual da mulher como inspiradora e guia acha a sua expressão mais bela" (Jaeger, 1995: 48).

Dessa maneira, o mito de Atena enquanto guardiã e protetora denota a imagem da mulher figura preservadora, mantenedora da cultura helênica. Nesse ponto, retomamos a questão da relação da deusa com Telêmaco e com os heróis de uma forma geral. Compreende-se que a função de educadora e protetora está fortemente presente através do aspecto feminino da divindade, ressaltando seu lado materno e exaltando seu caráter feminino como elementos preponderantes para a função de protetora e educadora do herói, quando comparados com seus atributos relativos à guerra e ao universo masculino como um todo.

Em outra obra, a Teogonia de Hesíodo, Atena aparece novamente auxiliando um herói, dessa vez Héracles, porém ao invés de lhe incutir mais força e coragem, ou protegê-lo na batalha, a deusa aparece como conselheira:

[...] mas o descendente de Zeus, o filho de anfitrião, Heracles, destruiu o monstro de forma implacável, com a ajuda do belicoso Iolao 
e com conselhos de Atena, a colecionadora de espólios. (Hesíodo, Teogonia, vv. 314-318: 41)

O monstro descrito no excerto acima é a Hidra de Lerna, uma espécie de dragão com nove cabeças de serpente, morta por Héracles no segundo de seus doze trabalhos. Atena auxilia Heracles com conselhos sobre como derrotar o monstro e, posteriormente, sugere que o herói banhe suas flechas no sangue da Hidra, tornado -as venenosas.

Podemos concluir, dessa forma, que nas fontes literárias, principalmente nos poemas homéricos, a forma mais comum de proximidade entre Atena e o herói está na representação dela enquanto uma conselheira do herói. É um tipo de representação que traz de forma mais clara a ideia do tutor, daquele que protege e auxilia o herói a encontrar o seu caminho, a amadurecer, encorajar e desenvolver ao máximo seus atributos heroicos e, portanto, masculinos.

Destacamos uma representação iconográfica que caracteriza essa função da deusa a partir da análise do vaso número 02 (Vaso Coleção Privada, Suíça; Número arquivo Beazley: 340539). Na cena presente na face $B$ do vaso 2 (fig. 3$)^{8}$, Héracles aparece ao centro entregando um javali a Eristeu, enquanto Atena está a sua direita e Hermes a sua esquerda. A posição de Atena próxima ao herói pode ser interpretada como uma forma de auxílio, proteção ou, ainda, inspiração, encorajamento.

8 Referências bibliográficas sobre o vaso: Beazley, J.D., Paralipomena (Oxford, 1971): 130.5BIS; Carpenter, T.H., with Mannack, T., and Mendonca, M., Beazley Addenda, 2nd edition (Oxford, 1989): 78

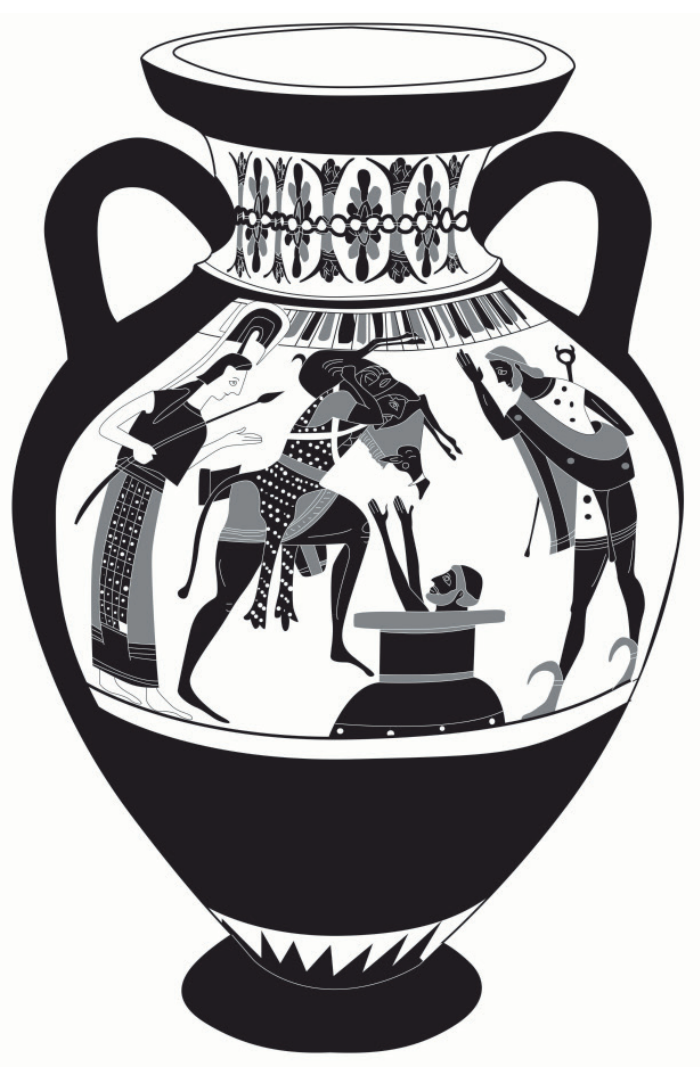

Fig 3. Atena auxiliando Heracles, face $\mathrm{A}$ do vaso $\mathrm{n}^{\circ} 02$ (Vaso Coleção Privada, Suíça; Número arquivo Beazley: 340539). Desenho: Yannis Nakas (2015). 
Ao mesmo tempo em que o vaso $\mathrm{n}^{\circ} 02$ possui em uma das faces uma cena heroica, uma cena de guerreiros, típica do universo masculino, na outra face possui deusas femininas, provavelmente Deméter e Perséfone em uma biga, acompanhadas de uma figura feminina que carrega uma coroa de flores, possivelmente uma grinalda (fig. 4).

É importante ressaltar que segundo o mito dessas duas divindades femininas, Deméter e Perséfone (mãe e filha), antes de ser raptada por Hades e de se tornar, portanto, deusa do mundo subterrâneo, do inferno (Perséfone propriamente dita), ela era a Kóre (do grego antigo: Kópๆ, que significa literalmente a "jovem, virgem"), a jovem virgem, filha de Zeus e Deméter. As duas deusas são comumente representadas juntas na iconografia dos Períodos Arcaico e Clássico, e muitas vezes, em carruagens fazendo referência ao mito. Estão ligadas à agricultura, à fertilidade, ao ciclo da vida e, dessa forma, em grande parte, ao universo feminino, principalmente a relação mãe e filha e ao casamento, enquanto um elemento de separação desse elo, da perda da virgindade e da incorporação da jovem virgem ao oîkos do marido, transformando-se em cidadã e geradora de futuros cidadãos. Portanto, a cena da face $\mathrm{A}$ do vaso número 02 faz referência explícita aos atributos de Atena pertencentes ao universo feminino por meio da imagem das duas deusas e da figura feminina que segura uma coroa de flores. Tal cena se contrapõe à cena presente na face $\mathrm{B}$, cujos elementos iconográficos fazem referência nítida aos atributos de Atena enquanto elementos pertencentes ao universo masculino.

Podemos inferir, dessa forma, com base nesta breve análise das fontes materiais e literárias,

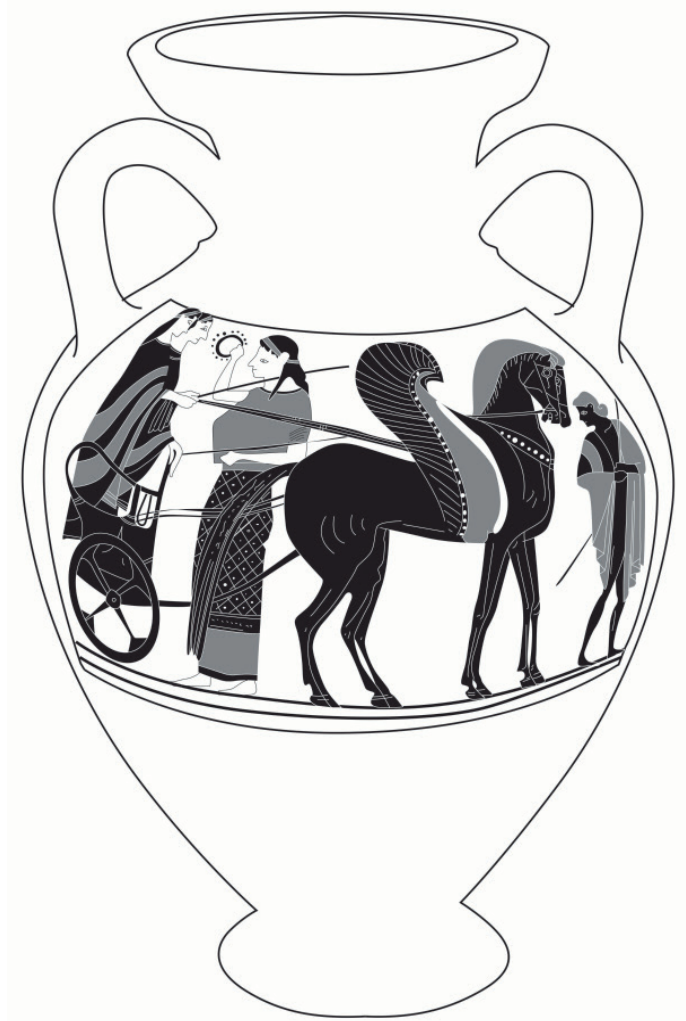

Fig 4. Demeter e Perséfone em uma carruagem, face B do vaso n 02 (Vaso Coleção Privada, Suíça; Número arquivo Beazley: 340539). Desenho: Yannis Nakas (2015). 
que o aspecto feminino de Atena é, em grande medida, indissociável da formação do herói e, assim, o universo masculino e o feminino aparecem nessas representações como elementos complementares e não em oposição.

\section{Atena e Cassandra}

Atena Prómakhos e Atena Palladium são representações da deusa comuns nos vasos em que a deusa aparece junto de Cassandra. Ambas as representações estão diretamente relacionadas com o mito da própria Cassandra, conforme explicita Francisco:

"Na Ática, essa Atena combativa foi utilizada na figuração do rapto de Cassandra. No século VI a.C., em figuras negras, a deusa aparece em esquema figurativo muito próximo do modelo panatenaico; assim como na figuração da Gigantomaquia, o que parece reforçar a constante relação entre a Atena panatenaica e o mito da Gigantomaquia" (Francisco, 2012: 51).

Segundo o mito, quando Troia é sitiada, Cassandra esconde-se no templo de Atena buscando proteção. O herói grego Ájax entra no templo, encontra Cassandra abraçada e suplicando a estátua de Atena e, mesmo assim, a retira violentamente de perto da estátua e a estupra em seguida (Eurípedes, As Troianas, vv. 95-96), causando a ira da deusa que, posteriormente, como vingança pela profanação do herói, dificulta o trajeto dos navios gregos (EURÍPIDES, As Troianas, vv. 103-115):

\section{“(...) Atena}

Sabes a afronta que me fizeram em meu templo?

Poseidon

Quando Ájax constrangeu Cassandra duramente?

Atena

E os gregos não o censuraram nem puniram! Poseidon

Mas foi com teu apoio que venceram Tróia. Atena
Mas pelo ultraje, unida a ti vou castigá-los. Poseidon

Terás a minha ajuda. Quais são teus planos?

Atena

Quando partirem suas naus daqui de Tróia Levando-os de retorno ao lar, conforme

esperam.

Zeus as fustigará com chuvas em torrentes

E tempestades escurecerão os céus;

Meu pai nos cederá o fogo de seus raios

Para com eles açoitarmos os soldados

E incendiarmos suas naus; faze tu mesmo

Vagas enormes estrondarem sobre a rota

Amontoando em turbilhões no Egeu as

ondas

E enchendo de cadáveres o mar sulcado

De Eubéia para que os gregos enfim

aprendam

A respeitar os meus altares no futuro

E a venerar os outros deuses como é justo." (EURÍPIDES, As Troianas, wv. 95-115: 174-175.)

Analisando a ânfora no 3 (Munich, Antikensammlungen: J617; Número arquivo Beazley: 310294$)^{9}$, visualizamos na Face A (Fig. 5) uma cena em que Cassandra está diante da Atena Palladium. Observa-se que a figura de Cassandra é representada de joelhos diante da estátua e aparece vestida, com o tórax completamente coberto.

Contudo, quando comparamos a imagem do vaso $\mathrm{n}^{\circ} 03$ com uma cena em que aparece Cassandra junto à representação da deusa, destacamos uma diferença fundamental nos elementos iconográficos que definem as imagens da Cassandra. A ânfora no 4 (London, British

9 Referências bibliográficas sobre a ânfora: Beazley, J.D., Attic Black-Figure Vase-Painters (Oxford, 1956): 135.34; Carpenter, T.H., with Mannack, T., and Mendonca, M., Beazley Addenda, 2nd edition (Oxford, 1989): 36; Corpus Vasorum Antiquorum: MUNICH, MUSEUM ANTIKER KLEINKUNST 1, 14-15, PLS.(108,109) 14.1, 15.1-3; Lexicon Iconographicum Mythologiae Classicae: VII, PL.675, KASSANDRA 60 (A) 


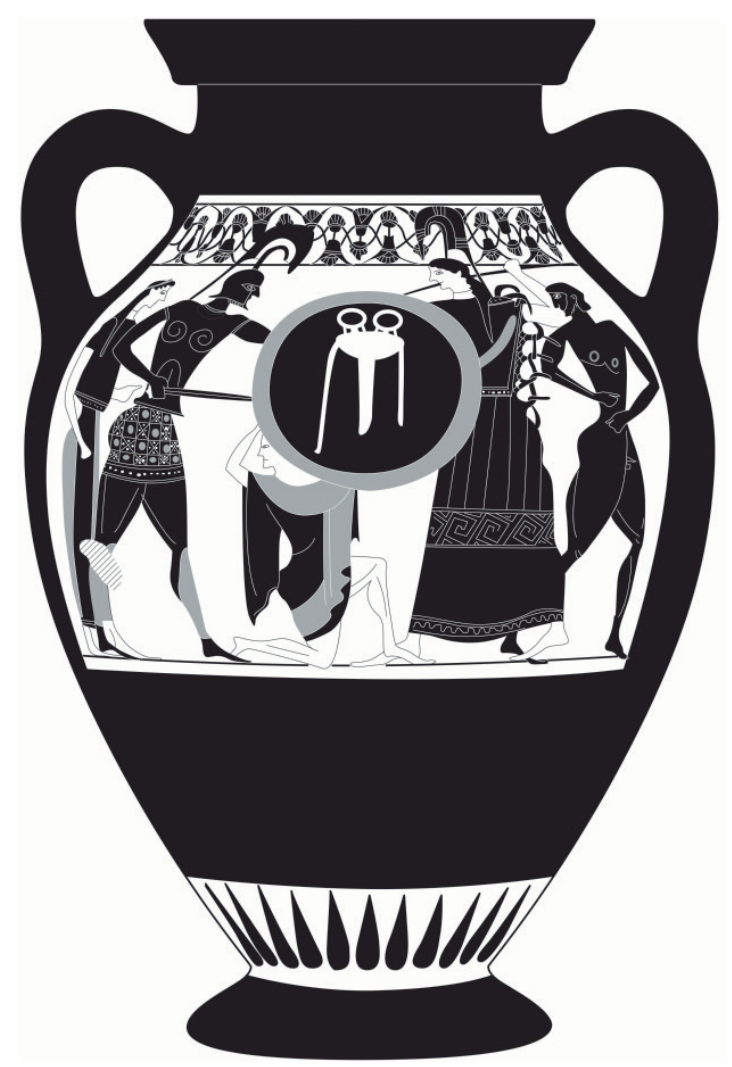

Fig 5. Cassandra diante de Atena Palladium ânfora n॰ 03 (Munich, Antikensammlungen: J617; Número arquivo Beazley: 310294). Desenho: Yannis Nakas (2015).

Museum: 1836.2-24.136; Número arquivo Beazley: 302941 ${ }^{10}$, na composição do painel iconográfico da face A (Fig. 6), Cassandra interage com Atena Prómakhos e aparece semiajoelhada e seminua, portando apenas um manto que expõe a parte superior do corpo, seu tórax, e suas pernas por completo.

É preciso observar que, em geral, na iconografia grega a mulher digna e honrada e,

10 Referências bibliográficas sobre o vaso: Beazley, J.D., Attic Black-Figure Vase-Painters (Oxford, 1956): 393.2; Beazley, J.D., Attic Red-figure Vase-painters, 1st ed. (Oxford, 1942): 151.2; Carpenter, T.H., with Mannack, T., and Mendonca, M., Beazley Addenda, 2nd edition (Oxford, 1989): 103; Corpus Vasorum Antiquorum: LONDON, BRITISH MUSEUM 4, IIIHe.7, PL. (204) 59.2A-B Mediterranean Archaeology: 9/10 (1996/97) PL.20.1 (A) portanto, membro da aristocracia ateniense, representante da mulher geradora de cidadãos para a pólis, é representada sempre vestida como um elemento iconográfico indicador que ressalta sua Aretê. Na representação das jovens, que configuram as kórai, portanto, a vestimenta longa e os cabelos longos, presos sutilmente apenas com uma tiara na parte superior, reforçam e valorizam a Aretê enquanto virgindade, pureza e castidade, características essenciais das jovens aristocráticas atenienses.

A quantidade de representações iconográficas das canéphorae é pequena e restringe-se sobretudo entre 550 e 330 a.C. Elas aparecem portando um manto de corpo inteiro, carregando o cesto sacrificial e possuem sempre cabelos longos. Em nenhuma das cenas do friso do 


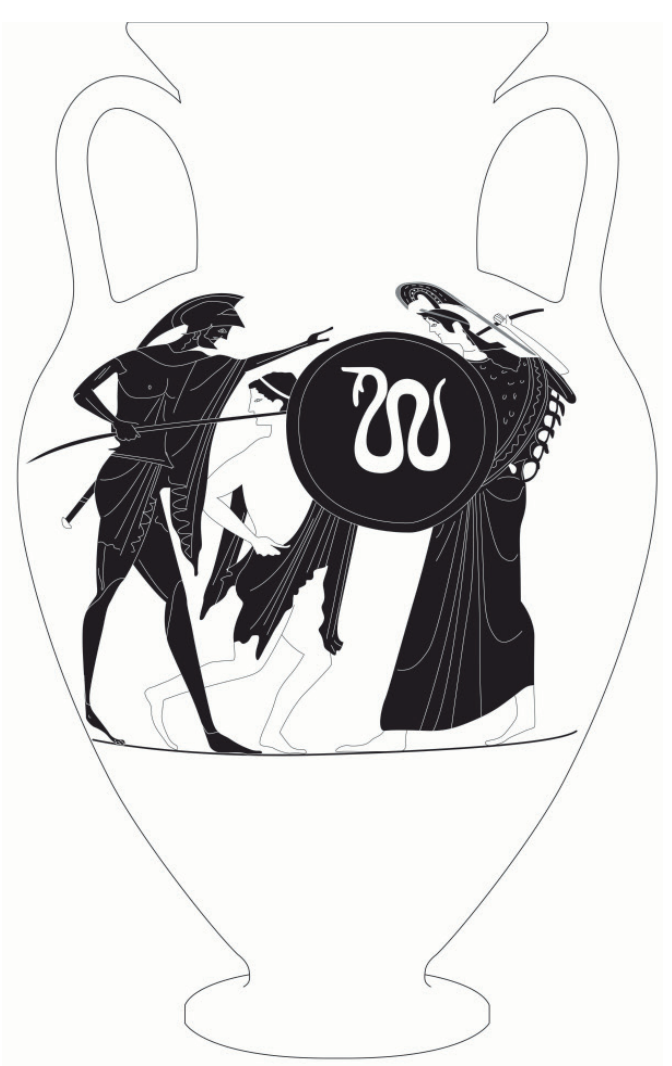

Fig 6. Cassandra diante de Atena Promakhos ânfora no 4 (London, British Museum: 1836.2-24.136; Número arquivo Beazley: 302941). Desenho: Yannis Nakas (2015).

Partenon, elas são retratadas portando cestos, porém aparecem vestidas com mantos longos e todas possuem longos cabelos.

Linda J. Roccos (1995) defende que tais jovens seriam canéphorae, apesar da ausência do cesto sacrificial. A autora relaciona as representações femininas do friso com a iconografia dos vasos do século VI a.C. que apresenta cenas de casamento. Nesses vasos, as jovens virgens, antes do casamento, são representadas sempre com mantos longos e possuem cabelos compridos. Dessa forma, as jovens do friso do Partenon seriam canéphorae que participam da procissão (ROCCOS, 1995: 654-659).

Verificamos que tais elementos iconográficos estão presentes nos vasos analisados, pois as jovens portam vestimentas longas e cabelos compridos, presos com uma tiara superior, como observamos nos detalhes das Figuras 1, 2, 4 e 7 .

Considerando a cena em que Cassandra aparece vestida (Fig. 5), notamos que Atena é representada como Palladium, ou seja, como estátua. Nessa imagem a deusa possui um papel inerte e não reage às súplicas de Cassandra, que ainda apresenta sua Arete preservada por meio de sua virgindade, pureza e castidade. Neste momento do relato mítico, a deusa privilegia o herói, Ájax, permanecendo estática, imóvel e permitindo, assim, que ele violente a jovem virgem. Podemos inferir que tais cenas representem o momento do mito em que Cassandra se refugia no templo da deusa e suplica por auxílio à estátua de Atena. 

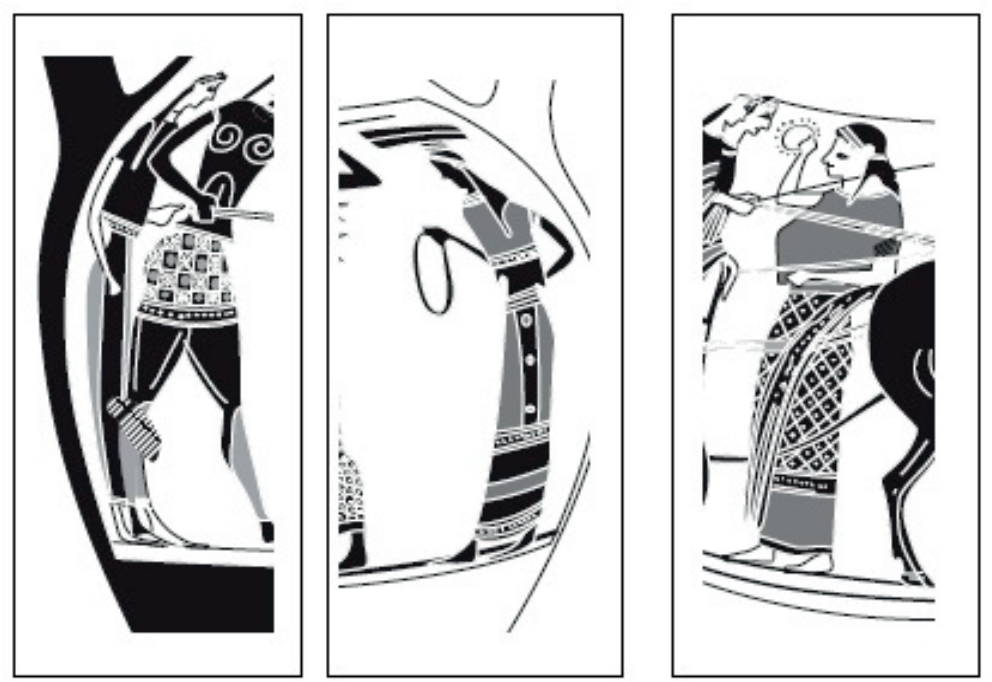

Fig 7. Representação iconográfica de figuras femininas. Detalhe extraído das figuras 1, 2 e 4. Desenho: Yannis Nakas (2015).

A importância da vestimenta na iconografia feminina como uma forma de preservação da Aretê, por meio da representação da virgindade característica das jovens mulheres solteiras, podemos sugerir que Cassandra, ao ser representada nua ou seminua, não possui mais sua Aretê, no caso sua virgindade, e dessa forma, a cena da face A do vaso número 04 (Fig. 6) retrata o momento do mito em que ela já teria sido violada por Ájax.

Observamos que nesta representação iconográfica, Cassandra aparece associada à Atena Prómakhos e podemos indicar, dessa maneira, que essa cena remete ao momento posterior da trama, no qual Cassandra aparece violada, ou seja, ela já teria perdido sua Aretê, sua virgindade. A deusa nessas imagens possui um papel ativo, ela vem em defesa de Cassandra, atacar Ájax, daí estar representada como Prómakhos e denotar a passagem do mito em que a deusa castiga a profanação do herói contra todos os barcos gregos.

Dessa maneira Atena se torna uma espécie de protetora da condição feminina, lembrando que ela própria opta pela virgindade e também vivencia uma situação semelhante à de Cassandra, quando Hefesto tenta violentá-la (PSEUDO
-APOLLODORUS, Bibliotheke, 3.14.6 ${ }^{11}$. Entretanto, ao mesmo tempo em que Atena assume esse papel de protetora da castidade feminina, ela é, por excelência, a divindade protetora do herói, e Ájax enquanto herói também é auxiliado e encorajado por ela.

Cabe-nos ressaltar que a própria relação entre as cenas presentes na face $\mathrm{A}$ e na face $\mathrm{B}$ desses dois vasos abre o debate sobre os atributos e papéis de Atena. Notamos que, simultaneamente, isto é, no mesmo vaso, a deusa protege a figura feminina em uma das faces e,

11 Trecho em inglês: "Book 3. Chapter 14. Athena came to Hephaestus, desirous of fashioning arms. But he, being forsaken by Aphrodite, fell in love with Athena, and began to pursue her; but she fled. When he got near her with much ado (for he was lame), he attempted to embrace her; but she, being a chaste virgin, would not submit to him, and he dropped his seed on the leg of the goddess. In disgust, she wiped off the seed with wool and threw it on the ground; and as she fled and the seed fell on the ground, Erichthonius was produced". PSEUDO-APOLLODORUS, Bibliotheke. FRAZER, James G. (tradução). The Library. Volume II. Book 3. 10-16. Loeb Classical Library (no. 122): Londres, 1921. Disponível em: http://www.perseus.tufts.edu/hopper/text?doc=Perseus:text:1999.01.0022:text=Library ook=3: chapter $=14$ (consulta: 27/05/2015) 
na outra, apresentam-se elementos do universo masculino como na face B do vaso 4 (Fig. 8) com a representação de Dionísio e seus sátiros que pode remeter aos simpósios, espaços proibidos às mulheres, ou ainda, como na face $\mathrm{B}$ do vaso 3 (Fig. 9) que apresenta uma carruagem conduzida por um homem, uma biga, remetendo a um episódio guerreiro ou de competições e jogos típico do universo masculino.

Outro exemplo dessa dualidade do caráter da deusa, de um lado exteriorizando seus atributos ligados ao universo feminino e, de outro, reforçando seus elementos masculinos, pode ser observado na cena que se desenvolve na face $\mathrm{A}$ do vaso 4 (Fig. 6). Verificamos a representação do episódio mítico da Cassandra e destacamos que o escudo de Atena possui como epísema uma cobra. A figura da serpente no escudo da deusa remete diretamente ao mito da Medusa,

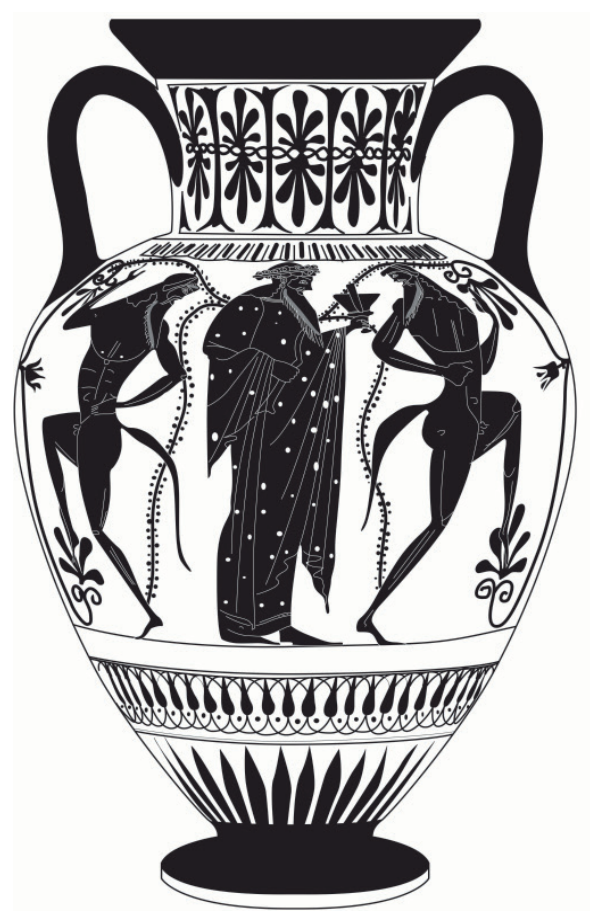

Fig 8. Dionísio entre sátiros que dançam, face B ânfora $n^{\circ} 4$ (London, British Museum: 1836.224.136; Número arquivo Beazley: 302941). Desenho: Yannis Nakas (2015) quando o herói Perseu, com o auxílio de Atena, por meio do escudo que a mesma havia lhe dado de presente, decapta a entidade feminina com cabelos de serpentes.

Perseu oferta a cabeça de Medusa para Atena. Em algumas versões, a deusa a coloca na ponta de sua lanças, em outras, no escudo. Dessa maneira, podemos inferir que nesta ânfora, novamente, a iconografia se apresenta como um recurso, uma forma de expressar a relação de Atena com o universo masculino, neste caso, enquanto tutora do herói Perseu.

Dessa forma, ressaltamos a estreita associação entre as imagens presentes nas faces A e B dos vasos que indica a dualidade que caracteriza Atena, de um lado exteriorizando seus atributos ligados ao universo feminino e, de outro, reforçando seus elementos masculinos de uma forma complementar.

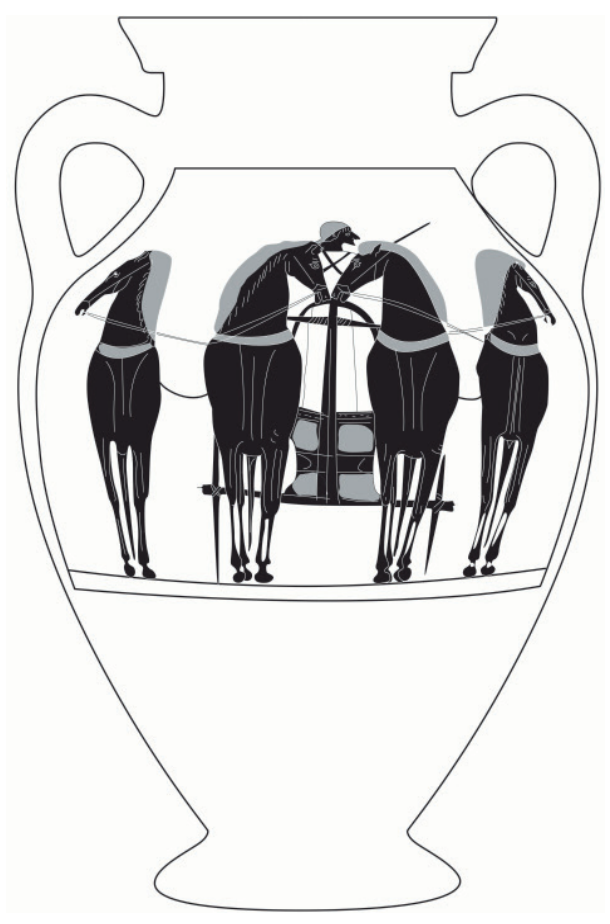

Fig 9. Carruagem conduzida por homem, face B da ânfora no 3 (Munich, Antikensammlungen: J617; Número arquivo Beazley: 310294). Desenho: Yannis Nakas (2015). 


\section{Considerações Finais: aspectos da análise iconológica.}

Este resumido exercício de análise das cenas nas ânforas áticas de figuras negras permitiu a identificação de três temáticas iconográficas centrais: A) a deusa e suas relações com os festivais em sua homenagem; B) a deusa e suas relações com o universo masculino por meio das interações com heróis e C) a deusa e suas relações com o universo feminino por meio das associações com a representação imagética do mito de Cassandra. Destacamos que nas três temáticas há um elemento central que caracteriza a deusa: a relação complementar entre os atributos do mundo masculino e do universo feminino. Nota-se que essa relação complementar entre masculino e feminino acontece tanto dentro de uma mesma cena presente em uma das faces dos vasos, quanto no diálogo entre as cenas presentes nas duas faces dos suportes materiais das imagens, as ânforas.

A interação entre masculino e feminino dentro da mesma cena são expressas por meio elementos iconográficos como figuras femininas portando vestidos e cabelos longos, presos com uma tiara, coroas de flores, a caixa sacrificial, entre outros, que remetem à atributos tipicamente femininos, como a Aretê enquanto virgindade, pureza e juventude. Tais elementos iconográficos são apresentados junto com referenciais que representam a Aretê masculina, enquanto a coragem, a força física, a juventude guerreira, expressadas por exemplo, por meio da nudez das figuras masculinas e da presença de instrumentos de batalha, como lança, arco e flecha, armadura, entre outros. Essas imagens rementem a ações cotidianas e sociais como os rituais e as atividades que constituíam as panateneias (Fig. 2), por exemplo, ou ainda, como na representação de Dionísio e os sátiros referindo-se aos simpósios (Fig. 8).

Percebemos que esses elementos de coexistência entre os mundos masculino e o universo feminino também estão presente em cenas explicitamente heroicas e míticas como na cena em que aparece Deméter e Perséfone (Fig. 4), da representação do próprio mito de
Cassandra (Fig. 5) (Fig. 6) e, ainda, na cena em que aparece o herói Héracles (Fig. 3).

Todas essas cenas apresentam uma complementaridade dos gêneros opostos, masculino e feminino, por meio da representação iconográfica. Além disso, essa relação complementar entre masculino e feminino pode ser verificada também na associação entre as duas faces diferentes do mesmo vaso; de um lado, representações caracterizadas com elementos da Aretê masculina e, do um lado da ânfora, referenciais da Aretê feminina. Relembrando que mesmo nas cenas preponderantemente de contexto masculino há figuras ou elementos do universo feminino e vice-versa.

Mediando essas relações entre o masculino e o feminino está Atena, transitando entre os dois universos do vaso e integrando as cenas. A deusa ocupa o espaço masculino através de seus atributos de deusa da guerra e protetora do herói, portanto atributos típicos da Aretê masculina e, ao mesmo tempo, ocupa o espaço feminino por meio de sua opção por ser uma deusa parthénos, ou seja, uma deusa virgem, possuindo assim a característica principal da Aretê feminina que é a virgindade.

Quando a mulher se casa e, portanto, perde sua virgindade, ela passa para a posição social de senhora do oîkos e, portanto, sua Aretê passa a ser identificada principalmente pela virtude de gerar cidadãos, de educar e formar o homem guerreiro, o cidadão. A medida que Atena é tutora, educadora do herói, ela passa a também ser detentora desse aspecto da Aretê, sem, no entanto, perder sua Aretê enquanto virgindade. Ela representa, assim, simultaneamente, os papéis da mulher enquanto moça e virgem e enquanto mulher adulta e mãe.

Atena só pode ser protetora do guerreiro, do masculino, por possuir o atributo feminino, materno e, ao mesmo tempo, ela só possui os atributos femininos por proteger o guerreiro, ligando-se ao masculino. Cassandra busca refúgio e suplica por ajuda da deusa Atena em particular devido à empatia que a divindade poderia sentir em relação à sua angústia. Atena é dotada da Aretê da virgindade feminina que possibilitaria a compreensão do pedido de Cassandra, porém ela é munida também da 
Aretê masculina enquanto coragem, bravura e guerreira que possibilitaria sua proteção e sua defesa em relação a Ájax.

Dessa maneira, podemos concluir que este breve e preliminar exercício de análise iconográfica, nos permite inferir que ao invés de pensar- mos as representações de Atena fundamentadas por dicotomias entre os gêneros masculino e feminino, ele abre caminhos para discutirmos complementaridades entre os dois atributos da deusa por meio dos quais um gênero não pode existir sem a presença e a essência do outro.

CORREIA, L.C; SOUZA, C.D. Representations of Athena in black-figured amphorae of the sixth century BCE: an exercise of iconographic. R. Museu Arq. Etn., 25: 83$103,2015$.

\begin{abstract}
This paper presents the main results and reflections obtained from an exercise of iconographic description and iconological analysis proposed for a small set of black-figure amphorae dating from the sixth century BC. This has as its central theme the iconographical representations of the goddess Athena depicted on one or on both sides of the vase, in order to understand them through the relationship with the other iconographic themes and characters on the scenes displayed on the amphorae.The methodology and purposes of this research include the study, classification, iconographic description and iconological analysis of this type of archaeological record selected, which means, the pottery and the black-figure representations of Athena, comparing it to some literary excerpts. Our aim, therefore, is to reflect and discuss the possible roles and attributes of the goddess as a male and a female figure. The results obtained from this analysis indicate complementary aspects in the attributes of the divinity that characterize her with qualifications of the male and the female worlds of the Athenian society of the Archaic Period, allowing her to move between both spaces.
\end{abstract}

Key-words: Athena, amphora, representation, iconographic analysis.

\title{
Referências Bibliográficas
}

Fontes textuais:

Eurípedes, As Troianas. KURY, Mário da G. (tradução). 6a edição. Jorge Zahar Editor: Rio de Janeiro, 2003.

Pseudo-Apollodorus, Bibliotheke. FRAZER, James G. (tradução). The Library. Volume II. Book 3. 10-16. Loeb Classical Library (no. 122): Londres, 1921.

Hesiodo. O trabalho e os dias. São Paulo: Iluminuras, 1991.
Hesiodo. Teogonia. Niterói: Editora da Universidade Federal Fluminense, 1986.

Homero. Ilíada. Tradução brasileira de Carlos Alberto Nunes. São Paulo, Hedra,

Homero Odisséia. Tradução brasileira de Trajano Vieira.São Paulo, Editora 34, 2011.

Bibliografia Geral.

Baltazar, G. S. O corpo ideal: um estudo sobre o feminino na Arte régia do reino novo (cc. 1550- 
1070 a.c.). Revista electronica de Antiguidade. Disponível em: http://www.nea. uerj.br/nearco/arquivos/numero8/3.pdf. Acesso 03/06/2014

Beazley, J. The Development of Attic Black-

Figure. University Of California

Press, 1951. Disponível em: http:// publishing.cdlib.org/ucpressebooks/ view?docId=ft1f59n77b\&chunk. id $=$ d0e1580\& toc.depth $=1 \&$ toc. $\mathrm{id}=\&$ brand $=$ eschol Acesso em: 05/07/2014

Beazley, J. D. Attic black figure vase painters. Oxford: Clarendon Press, 1956.

Beazley, J. D. Attic red figure vase painters. 3 vols., 2a. ed. Oxford: Clarendon Press, 1963.

Boardman, J. Athenian black figure vases. A handbook. London: Thames and Hudson, 1991.

Boardman J. Athenian Red Figure Vases: the archaic period. A Handbook. NY: Thames and Hudson, 1995.

Boardman J. Early Greek Vase Painting. 11th to 6th Centuries BC. Thames and Hudson: London, 1998.

Boardman J. The History of Greek Vases: potters, painters and pictures. London: WW Norton \& Co., 2006.

Condilo, Camila da Silva. A identidade feminina na historiografia sobre as mulheres da Grécia antiga. Alétheia: Revista de estudos sobre Antiguidade e Medievo, [s.l], v. 1, p.1-9, 2009. Disponível em: http://www.revistaaletheia.com.br/anteriores_4.html

Cook, R. M. Greek painted pottery. Londres: Methuem \& Co., 1960.

Correia, Larissa. Representações de Atena em ânforas de figuras negras do século VI a.C.: um exercício de análise iconográfica. Monografia apresentada para a obtenção do título de especialista em Arqueologia do curso de
Pós-graduação em Arqueologia, História e Sociedade da Universidade de Santo Amaro (UNISA) em 2014.

Dias, C. K. B. O Pintor de Gela. Características formais e estilísticas, decorativas e iconográficas. Tese de Doutorado, 2 vols. São Paulo: Universidade de São Paulo, 2009.

Florenzano, M. B. B. Nascer, Viver e Morrer na Grécia Antiga. São Paulo: Atual editora, 1996.

Francisco, G. da Silva. Panatenaicas: tradição, permanência e derivação. 2012. 364f. Tese de doutorado. Museu de Arqueologia e Etnologia. Universidade de São Paulo. São Paulo, 2012. Disponivel em: http://www. teses.usp.br/teses/disponiveis/71/71131/ tde-16052012-141348/pt-br.php

Jaeger, W. Paidéia, A formação do Homem Grego. São Paulo: Martins Fontes editora, 1995.

Loraux, N. "O que é uma deusa?" In: DUBY G., PERROT M. História das Mulheres - Antiguidade, Porto: Edições Afrontamento, 1990.

Malhadas, D.; Dezotti, M. C. C.; NEVES, M. H. M. (org.) DICIONARIO GREGO-PORTUGUES, V.4 $(\alpha-\delta)$. Cotia: Ateliê Editorial, 2006.

Meneses, U. T. B. "Cultura material no estudo das sociedades antigas". Revista de História, São Paulo, n.115, jul.-dez. 1983:103-117.

Morgan, C. Athletes and Oracles. Cambridge: CUP, 1990.

Richter, G. M. A. A handbook of Greek art. London: Phaidon Press, 1996 (9º edição).

Richter, G. M. A.; MILNE, M. Shapes and Names of Athenian Vases. Plantin, 1935, McGrath, 1973.

Roccos, L. J. "The Kanephoros and her Festival Mantle in Greek Art", American Journal of Archaeology, Vol. 99, No. 4, October 1995, pp. 641-666 
Sarian, H. "A cerâmica como documento arqueológico”. Revista de Pré História 6, 1984: 195-204.

Sarian, H. "Vasos Clássicos, ceramografia e ceramologia: algumas reflexões”. Cerâmicas da Quinta da Boa Vista, Rio de Janeiro. Catálogo da Exposição, 16.nov.1995 a 16.03.1996. Rio de Janeiro: Museu Nacional de Belas Artes, 1996: 31-38.

Trabulsi, J. A. D. Religião e Política na Grécia das Origens até a Polis Aristocrática. São Paulo:
Revista Clássica, 1993.VERMEULE, E. Greece in the Bronze Age. Chicago, London: University of Chicago Press, 1964.

Vernant, J.-P. As Origens do Pensamento Grego. São Paulo: Difel editora, 1986.

Vernant, J.-P. Mito e religião na Grécia antiga. São Paulo: Papirus, 1992

Vernant, J.-P. \& Vidal-Naquet P. Mito e tragédia na Grécia antiga. São Paulo: brasiliense, 1991. 